Гуменюк Б. М. / Застосування технологій кровозбереження при хірургічному лікуванні аортальних вад серця...

https://doi.org/10.30702/ujcvs/19.3609/062035-039

УДК 616.126.42-089.5

Гуменюк Б. М., д-р філософії, ст. наук. співробітник відділу анестезіології, інтенсивної терапії та штучного кровообігу

Попов В. В., д-р мед. наук, завідувач відділення хірургії набутих вад серця

Гуртовенко А. М., лікар-анестезіолог, мол. науковий співробітник, відділення хірургічного лікування набутих вад серця

Кліменко С. Н., завідувач біохімічної лабораторії

ДУ «Національний інститут серцево-судинної хірургії імені М. М. Амосова НАМН України», м. Київ, Україна

\title{
Застосування технологій кровозбереження при хірургічному лікуванні аортальних вад серця в умовах штучного кровообігу
}

\begin{abstract}
Резюме. Альтернативою стандартному застосуванню препаратів донорської крові під час операцій протезування аортального клапана в умовах штучного кровообігу була запропонована кровозберігаюча технологія як метод уникнення різних ускладнень у періопераційному періоді. У відділенні хірургії набутих вад серця НICCХ імені М. М. Амосова з 01.01.2011 по 01.01.2019 р. виконано ізольоване протезування аортального клапана у 680 пацієнтів, з яких у 452 пацієнтів не використовували компоненти донорської крові під час оперативного втручання. Описана методика проведення анестезіологічних та інфузійно-перфузійних заходів при протезуванні аортального клапана в умовах штучного кровообігу.

Час перебування в хірургічному стаціонарі становив 9,2 $\pm 1,1$ доби. Застосування методики кровозбереження дозволило отримати хороший клінічний ефект без трансфузійних ускладнень у періопераційному періоді, що сприяло зменшенню часу перебування на штучній вентиляції легень - $311,4 \pm$ 4,8 години до $7,1 \pm 3,9$ години. Знизилась також і кількість післяопераційних інфекційних ускладнень в основній групі відносно групи порівняння з $2,9 \%(\mathrm{n}=13 / 452)$ до $7,5 \%(\mathrm{n}=17 / 228)$ та час перебування у відділенні інтенсивної терапії з 87,2 $\pm 24,6$ до 64,7 $\pm 16,8$ години.
\end{abstract}

Ключові слова: хірургічне лікування аортальної вади серия, кровозберігаюча технологія, штучний кровообіг.

Переливання компонентів крові становить небезпеку зараження різними інфекційними, бактеріальними, вірусними та іншими захворюваннями $[1,2]$. Крім того, зростає ризик трансфузійних реакцій різного характеру, зумовлений підвищеною імуносупресивною дією препаратів крові [3, 4]. За період зберігання консервованих препаратів крові значно знижується рівень 2,3-дифосфогліцерату, що негативно впливає на оксигенацію тканин. Також проти переливання компонентів крові виступають Свідки Єгови, що є важливим соціальним чинником. Ураховуючи ці фактори та підвищений інтерес до безкровних технологій [5-8] в НІССХ імені М. М. Амосова було застосовано кровозберігаючі технології у хворих з ізольованим протезуванням аортального клапана в умовах штучного кровообігу (ШК).

Мета роботи - дослідити сучасні можливості хірургічного лікування аортальних вад серця без застосування препаратів крові в умовах штучного кровообігу.

Матеріали та методи дослідження. 3 01.01.2011 по 01.01.2019 р. проведений аналіз дослідження 680 пацієнтів, які перебували на лікуванні у відділенні хірургії набутих вад серця НICCX імені М. М. Амосова та були прооперовані з приводу аортальних вад серця в умовах ШК.

Пацієнти з аортальними набутими вадами серця були розділені на 2 групи: основна група -452 пацієнти, в яких не були застосовані препарати донорської крові, та група порівняння - 228 пацієнтів, у яких переливали компоненти донорської крові.

Основна група включала 241 (53,3\%) чоловіка і 211 $(46,7 \%)$ жінок віком від 17 до 73 років (середній вік $53,7 \pm 5,2$ року).

У групу порівняння ввійшли $129(56,7 \%)$ чоловіків і $99(43,3 \%)$ жінок віком від 17 до 70 років (середній вік $51,7 \pm 4,8$ року).

Усім пацієнтам була виконана корекція аортального клапана в умовах ШК.

У 327 (72,3\%) пацієнтів основної групи, як і в 155 $(67,9 \%)$ пацієнтів групи порівняння, переважає ізольоване протезування аортального клапана (ПАК).

Для основної групи були розроблені та впроваджені методики кровозбереження. Нами вироблені критерії показань до інтраопераційного резервування аутокрові 
при операціях хірургічної корекції аортальних вад серця в умовах ШК:

a) анамнестичні - відсутність в анамнезі анемії та відміна до операції за 7 днів препаратів, які впливають на згортальність крові;

б) вихіднілабораторні показники: гемоглобін $\geq 135$ г/л, гематокрит $\geq 39 \%$, тромбоцити $\geq 160 \times 109 / л$, еритроцити $\geq 3,8 \times 1012 / л$, білок $\geq 65$ г/л;

в) показники гемодинаміки після введення в наркоз центрального венозного тиску $\geq 5$ мм рт. ст. та середнього артеріального тиску (АТсер.) $\geq 110$ мм рт. ст. при первинному об'ємі циркулюючої крові (ОЦК) $\geq 4,3 \pm 0,5$ л.

У комплексі з іншими методами вищезазначені варіанти інтраопераційного резервування аутокрові при операціях хірургічної корекції аортальних вад серця виявились ефективними, що дало змогу відмовитися від переливання компонентів донорської крові.

Гематокрит пацієнтів у межах $(0,40)$ сприяв можливості доопераційної ексфузії аутокрові (варіант кровозбереження А). Резервування аутокрові за варіантом «А» являє собою поетапну ексфузію аутокрові від моменту розрізу шкіри до введення гепарину. Кров брали через центральний венозний катетер упродовж 30 хвилин під контролем центрального венозного та артеріального тиску. Одним із важливих елементів кровозбереження був контроль за водним балансом протягом усього періопераційного періоду, що досягалося як ретельним утриманням переднавантаження, так і стимуляцією діурезу, що забезпечувалося завдяки використанню загальною дозою 1 мг/кг фурасеміду і 0,15-0,3 г/кг маніту. У 247 пацієнтів із взяттям крові за варіантом «А» до початку ШК було задепоновано 418,6 \pm 92,7 мл крові, або 10,1 $\pm 2,8 \%$ ОЦК. Заповнення переднавантаження проводили об'ємом $10 \%$ розчину рефортану у співвідношенні до крові $1: 1$. Рівень гемоглобіну при ексфузії крові при цьому знизився із $136,3 \pm 11,4$ г/л до $119,6 \pm$ 9,8 г/л, гематокрит з $0,41 \pm 0,05$ до $0,36 \pm 0,03$, а білок 3 $67,4 \pm 4,1$ г/л до $61,5 \pm 5,2$ г/л.

Процедуру retrograde autological priming (RAP) виконали у 82 пацієнтів (варіант кровозбереження «В»). 3 його допомогою вдалося витіснити назовні із резервуара апарата штучного кровообігу (АШК) 468,1 \pm 79,3 мл первинного об'єму заповнення, що становило $11,4 \pm 1,9 \%$ від ОЦК, зменшивши, таким чином, гемодилюцію. Взяття гепаринізованої крові проводили із венозної магістралі апарата штучного кровообігу у фізіологічний блок АШК, витісняючи первинний об’єм заповнення в окремий резервуар (рисунок 1).

Чим вище рівень гематокриту в пацієнта, тим більше аутокрові можна заготовити. На цьому етапі необхідно максимально знизити величину гемодилюції після початку ШК за рахунок заповнення резервуара АШК аутокров'ю пацієнта. Оскільки ця процедура триває до 10 хвилин, препарати гемодинамічного впливу слід обмежити.

Якщо на початку ШК в оксигенаторі буде більше 1500 мл перфузату, гематокрит не нижче 0,4 , а вага пацієнта не менше 80 кг, то виконують варіант резервування (депонування) аутокрові (варіант кровозбереження «С»). Виконати цю процедуру вдалося в комбінації з варіантами «A» або «В» у 174 пацієнтів та як самостійний метод у 91 пацієнта (рисунок 2). Ексфузія перфузату становила 422,5 $\pm 107,3$ мл $(10,3 \pm 1,9 \%$ від ОЦК (розрахунковий об’єм ОЦК $4,1 \pm 0,4$ л)).

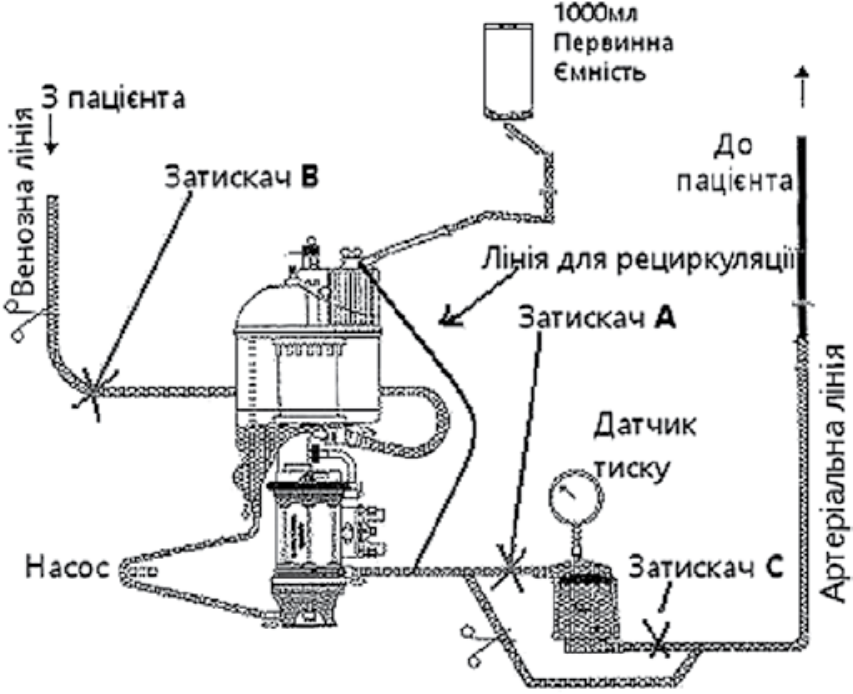

Рисунок 1. Депонування аутокрові в апарат штучного кровообігу з венозної магістралі (RAP) до початку перфузії. Варіант кровозбереження «В»

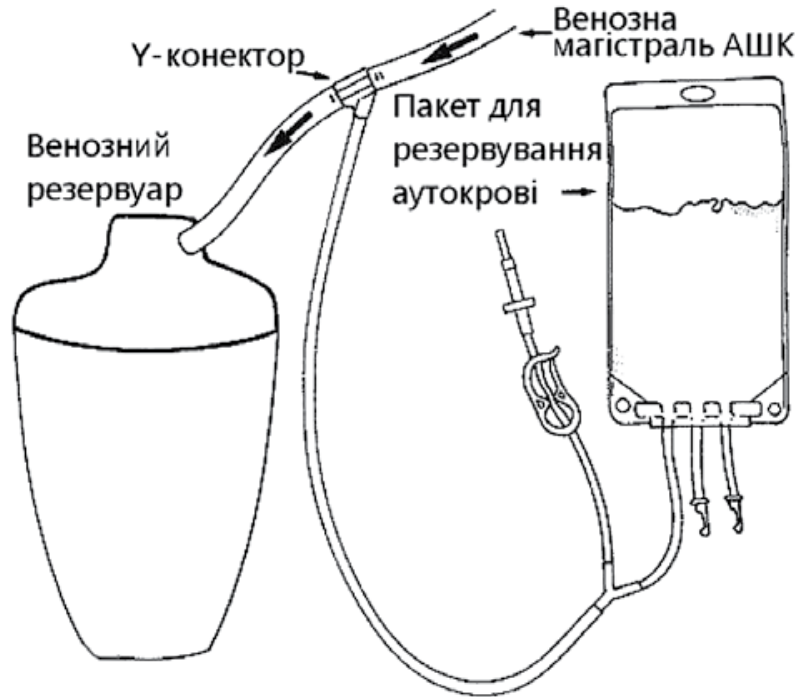

Рисунок 2. Депонування перфузату в АШК з венозної магістралі під час перфузії 
Гуменюк Б. М. / Застосування технологій кровозбереження при хірургічному лікуванні аортальних вад серця...

\section{Таблиця 1}

Динаміка ексфузії крові в групах резервування

\begin{tabular}{|c|c|c|c|c|c|}
\hline Група резервування & Ексфузія крові (мл) & RAP (мл) & $\begin{array}{l}\text { Ексфузія при вході в } \\
\text { перфузію із АШК (мл) }\end{array}$ & Усього (мл) & \% від ОЦК \\
\hline «A» & $418,6 \pm 92,7$ & - & - & $418,6 \pm 92,7$ & $10,1 \pm 2,8$ \\
\hline «A+B» & $397,6 \pm 75,9$ & $478,1 \pm 79,3$ & - & $875,7 \pm 92,5$ & $21,4 \pm 3,3$ \\
\hline$《 A+C »$ & $422,8 \pm 80,4$ & - & $464,7 \pm 132,2$ & $887,2 \pm 106,3$ & $21,6 \pm 2,7$ \\
\hline$《 A+B+C »$ & $437,0 \pm 67,6$ & $366,4 \pm 163,3$ & $388,6 \pm 104,5$ & $1192,0 \pm 115,2$ & $29,0 \pm 3,3$ \\
\hline «C» & - & - & $422,5 \pm 107,3$ & $422,5 \pm 107,3$ & $10,3 \pm 1,9$ \\
\hline
\end{tabular}

При варіанті кровозбереження «С» киснева ємність крові не зменшувалась.

У таблиці 1 порівнюються варіанти резервування аутокрові в основній групі. Найчастіший варіант ексфузії «А», як самостійний метод, був використаний у 247 (54,6\%) пацієнтів, а в комбінації з іншими варіантами ексфузії - у $378(83,6 \%)$ пацієнтів. Варіант «С» застосовували у $91(20,1 \%)$ пацієнта. Варіанти резервування «В» та «В + C» не використовували. На цьому етапі ексфузії аутокрові гемоглобін знижувався 3 $138,7 \pm 11,8$ г/л до 104,6 \pm 9,7 г/л, гематокрит - 3 0,37 \pm 0,04 до $0,31 \pm 0,03$, рівень білка при цьому знижувався - 3 67,4 \pm 3,6 г/л до 56,9 \pm 3,2 г/л, що зберігало достатній онкотичний тиск.

Під час ШК ми контролювали параметри кислотно-основного стану, вміст електролітів крові, рівень глюкози, лактату, гемоглобіну, білка крові. Крім того, оцінювали об'єм діурезу, температуру тіла, показники центрального венозного та артеріального тиску.

Усі операції виконували в умовах ШК і помірної гіпотермії $\left(32-35^{\circ} \mathrm{C}\right)$. Захист міокарда проводили на основі кристалоїдного розчину Святого Томаса з додаванням $22 \%$ аутокрові або розчину Кустодіолу.

Після завершення хірургічної корекції аортальної вади серця і зупинки апарата ШК перфузат із фізіологічного блоку АШК реінфузували в пацієнта під ретельним контролем гемодинаміки. При цьому активно застосовували $0,1 \%$ розчин ізосорбіду динітрату з метою збільшення об'єму циркуляторного русла пацієнта. Ретельний гемостаз виконували на всіх етапах операції. Водний баланс підтримували до початку перфузії в межах 0-400 мл, переливаючи лише 400 мл $6 \%$ рефортану для заміщення ОЦК під час ексфузії крові, та виходили на нульовий водний баланс на завершення операції. На етапі штучного кровообігу і до кінця перфузії водний баланс не перевищував 1500 мл, а наприкінці операції, за рахунок активного діурезу або гемоконцентрації, баланс рідини дорівнював нулю.

Результати та обговорення. У групі порівняння (228 пацієнтів) донорську еритроцитарну масу та плазму застосовували на всіх етапах операції. Загалом інтра- операційно було сумарно перелито 112000 мл еритроцитарної маси, що в перерахунку становить 511,8 мл на одного пацієнта, та 128600 мл свіжозамороженої плазми, що відповідає 564,9 мл на пацієнта. У відділенні інтенсивної терапії післяопераційна інфузія препаратів крові від загальної досягала 37,4 \%. У групах, які аналізуали, померлих на госпітальному етапі не було.

Усього на етапах періопераційного періоду в групі порівняння було використано 168792 мл еритроцитарної маси, що в перерахунку на одного пацієнта становило 825,4 мл, а свіжозамороженої плазми 153244 мл, що відповідає 649 мл на одного пацієнта.

В основній групі переливань препаратів крові під час операції не виконували. Від першої до третьої доби післяопераційного періоду було перелито еритромаси 117592 мл, що в перерахунку становить 260,1 мл на одного пацієнта, а свіжозамороженої плазми 127804 мл, що відповідає 282,7 мл на одного пацієнта.

Характер змін величин гемоглобіну на всіх етапах хірургічної корекції як в основній групі, так і в групі порівняння відображено в таблиці 2.

Відповідно до показників у таблиці динаміка рівня гемоглобіну в обох досліджуваних групах була достатньою для проведення оперативного втручання на аортальному клапані в умовах ШК. Оптимальним варіантом проведення операції протезування аортального клапана за безкровною технологією (ураховуючи динаміку Нb крові) $є$ варіант « A + В + С» з максимальною кількістю заготовленої та реперфузованої аутокрові. Відсутність переливання донорської крові в пацієнтів основної групи сприяла зменшенню часу перебування на штучній вентиляції легень - $311,4 \pm 4,8$ години до $7,1 \pm 3,9$ години, а тривалість перебування у відділенні інтенсивної терапії - з 87,2, $\pm 24,6$ години до $64,7 \pm$ 16,8 години $(\mathrm{p}<0,005)$. Знизилась також і кількість післяопераційних інфекційних ускладнень в основній групі відносно групи порівняння з 7,5 \% (n=17/228) до $2,9 \%(\mathrm{n}=13 / 452)$.

У ході проведеного порівнювального аналізу об'єму інтраопераційних крововтрат та величини ексудації за дренажами ми дійшли висновку, що в основній групі ці показники були менші, ніж у групі порівняння - 


\section{Таблиця 2}

Динаміка змін показників гемоглобіну (г/л) в основних групах та в групі порівняння на всіх етапах періопераційного nepiody

\begin{tabular}{|c|c|c|c|c|c|c|c|}
\hline \multirow[b]{2}{*}{ Групи } & \multicolumn{7}{|c|}{ Етапи } \\
\hline & $\begin{array}{l}\text { Початок } \\
\text { наркозу }\end{array}$ & $\begin{array}{l}\text { Початок } \\
\text { операції }\end{array}$ & $\begin{array}{l}\text { Початок } \\
\text { ШК }\end{array}$ & $\begin{array}{l}\text { Закінчення } \\
\text { ШК }\end{array}$ & $\begin{array}{l}\text { Кінець } \\
\text { операції }\end{array}$ & $\begin{array}{c}\text { Друга доба } \\
\text { після операції }\end{array}$ & Виписування \\
\hline $\begin{array}{l}\text { Bapiant «A» } \\
(\mathrm{n}=229)\end{array}$ & $135,5 \pm 16,0$ & $130,5 \pm 16,8$ & $96,2 \pm 16,0$ & $90,2 \pm 13,7$ & $108,3 \pm 14,4$ & $115,5 \pm 18,9$ & $110,9 \pm 13,0$ \\
\hline $\begin{array}{l}\text { Варіант «A + B» } \\
(\mathrm{n}=101)\end{array}$ & $131,2 \pm 15,3$ & $128,7 \pm 16,6$ & $99,5 \pm 11,2$ & $95,1 \pm 12,2$ & $115,4 \pm 9,7$ & $128,4 \pm 16,9$ & $107,0 \pm 18,0$ \\
\hline $\begin{array}{l}\text { Bapiant «A + C» } \\
(\mathrm{n}=23)\end{array}$ & $139,8 \pm 16,1$ & $132,2 \pm 14,8$ & $99,5 \pm 11,9$ & $95,1 \pm 11,8$ & $109,5 \pm 11,9$ & $127,2 \pm 16,0$ & $110,8 \pm 13,1$ \\
\hline $\begin{array}{l}\text { Bapiant «A + B + C» } \\
(\mathrm{n}=68)\end{array}$ & $140,4 \pm 12,1$ & $131,3 \pm 15,9$ & $103,1 \pm 14,6$ & $96,1 \pm 9,2$ & $116,3 \pm 9,8$ & $131,5 \pm 18,6$ & $120,0 \pm 10,9$ \\
\hline $\begin{array}{l}\text { Bapiaнт «C» } \\
(\mathrm{n}=31)\end{array}$ & $133,8 \pm 11,8$ & $133,9 \pm 17,6$ & $98,7 \pm 10,5$ & $93,4 \pm 10,4$ & $110,4 \pm 8,1$ & $124,6 \pm 19,5$ & $109,1 \pm 11,1$ \\
\hline $\begin{array}{l}\text { Група порівняння } \\
(\mathrm{n}=228)\end{array}$ & $136,0 \pm 15,7$ & $130,1 \pm 11,7$ & $90,1 \pm 12,5$ & $87,2 \pm 11,4$ & $102,9 \pm 12,0$ & $111,1 \pm 9,8$ & $111,8 \pm 14,7$ \\
\hline
\end{tabular}

\section{Таблиця 3}

\section{Періопераційна крововтрата у хворих з ПАК}

\begin{tabular}{lcccc} 
Показники & Основна група (n= 452) & \% від ОЦК & Група порівняння (n= 228) & \% від ОцК \\
\hline Інтраопераційна крововтрата & $203,6 \pm 44,2$ мл & $4,73 \%$ & $368,8 \pm 81,6$ мл & $8,5 \%$ \\
\hline Ексудація за дренажами, мл & $104,2 \pm 30,7$ мл & $2,4 \%$ & $133,7 \pm 28,4$ мл & $3,1 \%$ \\
\hline Усього & $307,8 \pm 37,5$ мл & $7,1 \%$ & $502,5 \pm 55$ мл
\end{tabular}

$291,4 \pm 43,5$ мл проти 588,3 $\pm 117,7$ мл (р < 0,05) (таблиця 3). Це значною мірою пов'язано як із переливанням у групі порівняння еритроцитарної маси зі зміненими структурними та функціональними властивостями (збільшені терміни зберігання та зменшення АТФ), і відповідно мікроциркуляторними порушеннями (мікротромбоз, сладж-синдром), та аутоімунними реакціями від переливання свіжозамороженої плазми.

\section{Висновки}

1. Впроваджена в клінічну практику методика безкровної хірургії при корекції аортального клапана в умовах ШК дозволила зменшити періопераційну крововтрату з 11,6 до 7,1\%.

2. Найефективніші варіанти кровозберігаючої технології за рівнем Нb спостерігались при варіанті резервування аутокрові «А + B + C». При цьому під час оперативної корекції аортального клапана в умовах ШК ексфузія $29 \%$ від ОЦК не призводила до зниження кисневої ємності крові та, відповідно, доставки та потреби кисню й розвитку лактатацидозу.

3. Відсутність алогемотрансфузій у пацієнтів основної групи сприяло зниженню кількості післяопераційних інфекційних ускладнень з 7,5\% в групі порівняння до 2,9 \% в основній групі.
4. Відсутність переливання компонентів крові в основній групі під час оперативного втручання на аортальному клапані в умовах ШК та значне їх зменшення в післяопераційному періоді відносно групи порівняння покращили загальні результати хірургічної корекції аортальних вад серця.

\section{Список використаних джерел References}

1. Гуменюк БМ. Виявлення маркерів інфекції, що передаються через кров у донорів та пацієнтів кардіохірургічного стаціонару. Щорічник наукових праць Асоціації серцево-судинних хірургів України. 2012;20:122-5. Gumeniuk BM. [Identification of infectious disease markers transmitted through the blood of donors and patients of a cardiosurgical hospital]. Shchorichnyk naukovyh prats Asotsiatsii sersevo-sudynnyh khirurhiv Ukrainy. 2012;20:122-5. Ukrainian.

2. Dietrich W, Lüth JU, Kormann J, Wick S, Kaiser W, Eberle B, et al. [Intraoperative blood requirements and allogeneic blood transfusion in cardioanesthesia. Data analysis of 7729 patients in 12 cardiac surgical clinics]. Anaesthesist. 1999;48(12):876-83. German. PMID: 10672351. https:// doi.org/10.1007/s001010050801

3. Жирбут ЕБ, Шестаков ЕА. Правила и аудит переливания крови : руководство для врачей. Под ред. Ю. Л. Шевченко. Москва: РАЕН; 2010. 
Zhyrbut EB, Shestakov EA. [Blood Transfusion Rules and Audit: guidelines]. Shevchenko YuL, editor. Moscow; 2010. Russian.

4. Jin R, Zelinka ES, McDonald J, Byrnes T, Grunkemeier GL, Brevig J; Providence Health \& Services Cardiovascular Disease Study Group. Effect of hospital culture on blood transfusion in cardiac procedures. Ann Thorac Surg. 2013 Apr;95(4):126974. https://doi.org/10.1016/j.athoracsur.2012.08.008

5. Curley GF, Shehata N, Mazer CD, Hare GM, Friedrich JO. Transfusion triggers for guiding RBC transfusion for cardiovascular surgery: a systematic review and meta-analysis. Crit. care Med. 2014 Dec;42(12):2611-24. https://doi.org/10.1097/CCM.0000000000000548

6. Лазоришинец ВВ, Попов ВВ, Гуменюк БН, Дьяченко ВЛ. Кровосберегающая технология в хирургии митральных пороков сердца. Кардиология в Беларуси. 2016;8(3):21-5.
Lazoryshynets VV, Popov VV, Gumenyuk BM, Diachenko VL. [Bloodsaving technology in surgery of mitral heart defects]. Kardiologiya v Belarusi. 2016;8(3):21-5. Russian.

7. Lewis CE, Hiratzka LF, Woods SE, Hendy MP, Engel AM. Autologous Blood Transfusion in Elective Cardiac Valve Operations. J Card Surg. 2005 Nov-Dec;20(6):513-8. https://doi.org/10.1111/j.1540-8191.2005.00137.x

8. Society of Thoracic Surgeons Blood Conservation Guideline Task Force, Ferraris VA, Ferraris SP, Saha SP, Hessel EA 2nd, Haan CK, et al. Perioperative blood transfusion and blood conservation in cardiac surgery: the Society of Thoracic Surgeons and The Society of Cardiovascular Anesthesiologists clinical practice guideline. Ann Thorac Surg. 2007 May;83(5 Suppl):S27-86. https:// doi.org/10.1016/j.athoracsur.2007.02.099

\title{
Blood-Sparing Technique during Surgical Treatment of Aortic Valve Disease under Cardiopulmonary Bypass
}

\author{
Gumeniuk B. M., Popov V. V., Gurtovenko A. N., Klimenko S. N. \\ National Amosov Institute of Cardiovascular Surgery, Kyiv, Ukraine
}

\begin{abstract}
The use of donated blood components in patients with acquired heart defects in the operative period is often associated with a variety of possible complications requiring the search for alternative measures to reduce their use. In the period from 01/01/2011 to 01/01/2019 at the Department of Surgery of Acquired Heart Defects of National Amosov Institute of Cardiovascular Surgery, isolated aortic valve replacement was performed in 680 patients divided into 2 groups. The main group included 452 patients in whom no donated blood components were used at the operative stage, and the comparison group included 228 patients who obtained blood products during the operative period. The technique of anesthesiological and perfusiological measures at the "bloodless" aortic valve replacement under cardiopulmonary bypass is described. In the main group, autologous blood collection in pre-perfusion period was not marked by sharp hemodynamic changes. Acute normovolemic hemodilution was performed with a $6 \%$ hydroxyethyl starch solution in a 1:1 ratio. The levels of $\mathrm{Hb}$, Hct and protein during the surgical intervention were at the stage of compensation. At Hct $\geq 39$, autologous blood was collected (variant A) before heparin administration. Under the central venous pressure control, water balance was evaluated during stimulation of diuresis. Variant A was perdominantly used. For variant A, Hb decrease from $13.6 \mathrm{~g} / \mathrm{L}$ to $11.9 \mathrm{~g} / \mathrm{L}$, and blood protein decrease from $67.4 \pm 4.1 \mathrm{~g} / \mathrm{L}$ to $61.5 \pm 5.2 \mathrm{~g} / \mathrm{L}$ were observed. The retrograde antological priming (RAP) variant $\mathrm{B}$ (displacement from the perfusate tank) was used in $11.4 \%$ of the total. In the comparison group, $511.8 \pm 117.7 \mathrm{ml}$ of packed RBC and $564.9 \pm 63.3 \mathrm{ml}$ of fresh frozen plasma per patient were transfused in the operating period. The length of stay in the ICU was $64.7 \pm 16.8$ hours in the main group, $87.2 \pm 24.6$ hours in the comparison group. The time spent in the surgical hospital was $9.2 \pm 1.1$ days in the main group and $11.8 \pm 3.3$ days in the comparison group. Implementation of the procedure described enabled to obtain good clinical effect without transfusion complications at the hospital stage.
\end{abstract}

Keywords: cardiopulmonary bypass, technique without using donor blood, aortic valve disease treatment.

Стаття надійшла в редакцію 03.09.2019 р. 